\title{
Benign Cephalic Histiocytosis: A Case Report
}

\author{
Rafet Koca, M.D., Sibel Bektaş ${ }^{1}$, H. Cevdet Altinyazar², Tuna Sezer \\ Departments of Dermatology, ${ }^{1}$ Pathology, Faculty of Medicine, Zonguldak Karaelmas University, Zonguldak, \\ ${ }^{2}$ Department of Dermatology, Selcuklu Medical Faculty, Selcuk University, Konya, Turkey
}

Histiocytic skin disorders are usually classified as either
Langerhans' cell histiocytosis ( $\mathrm{LCH}$ ) or non $\mathrm{LCH}$, based on
the pathology. Benign cephalic histiocytosis $(\mathrm{BCH})$ is a rare
type of non-Langerhans histiocytitic disorder and is
characterized by self-healing multiple small eruptions of
yellow to red-brown papules on the face and upper trunk.
Histologic features of this disorder show dermal proliferation
of histiocytes that have intracytoplasmic comma-shaped
bodies, coated vesicles and desmosome-like structures. In
this study, we report on a 7-month-old boy who contained
small yellow-red papules on his face that spread to his upper
trunk. The clinical and histologic features in this patient were
consistent with BCH. (Ann Dermatol 23(4) 508 $\mathbf{5 1 1 , ~ 2 0 1 1 ) ~}$

\section{-Keywords-}

Benign cephalic histiocytosis, Generalized eruptive histiocytoma, Infant, Juvenile xanthogranuloma, Non-LangerhansCell

\section{INTRODUCTION}

Benign cephalic histiocytosis $(\mathrm{BCH})$ is a rare, benign non-Langerhans histiocytitic disorder of infants and young children, and was first described by Gianotti et al. in $1971^{1}$. This disorder is characterized by a self-healing, asymptomatic and multiple small eruptions of yellow to

Received September 2, 2010, Revised December 6, 2010, Accepted for publication December 6, 2010

Corresponding author: Rafet Koca, M.D., Zonguldak Karaelmas Üniversitesi, Tıp Fakültesi Dermatoloji Anabilim Dalı, Kozlu 67600 Zonguldak, Turkey. Tel: 90-372-2613168, Fax: 90-372-2610155, E-mail: rafkoca@yahoo.com

This is an Open Access article distributed under the terms of the Creative Commons Attribution Non-Commercial License (http:// creativecommons.org/licenses/by-nc/3.0) which permits unrestricted non-commercial use, distribution, and reproduction in any medium, provided the original work is properly cited. red-brown papules, which develops initially on the head and neck. Histological studies have shown that dermal proliferation of histiocytes, which have intracytoplasmic comma-shaped bodies, coated vesicles and desmosomelike structure, occurs with this disorder ${ }^{2}$. There have been reports showing that $\mathrm{BCH}$ may have overlapping clinical and histologic features with some other non-Langerhans histiocytitic disorders, including juvenile xanthogranuloma (JXG) and generalized eruptive histiocytoma $(\mathrm{GEH})^{3}$. Here, we describe a 7-month-old boy that had clinicopathologic findings consistent with the diagnosis of $\mathrm{BCH}$.

\section{CASE REPORT}

A 7-month-old white boy was referred to our department with small discrete, asymptomatic, yellow-red papules, which were first observed on his face at 1 month. The number of papules gradually increased over the following weeks and spread to his upper trunk and upper arms. He was otherwise healthy and developmentally normal. Both his weight and height were at the 50th percentile. His parents were not consanguineous and the family history was unremarkable. Clinical examination at the time of presentation demonstrated multiple, scattered yellow-red monomorphic papules that were 2 to $5 \mathrm{~mm}$ over the face, upper trunk and upper limbs (Fig. 1, 2). Mucous membranes, palms, soles and teeth were normal. He had no organomegaly or lymphadenopathy. Neurodevelopmental and ophthalmic examinations were normal.

In the routine blood test, the haematologic and biochemical results were normal. Serum lipid screening (cholesterol, triglycerides, High-density lipoprotein (HDL)and low-density lipoprotein (LDL)-cholesterol), IgA, IgG, $\lg \mathrm{M}$, serum protein electrophoresis and syphilis serology were all normal or negative. X-ray screening of skeletal system showed no bony defects. An upper abdominal ultrasonography was interpreted to be normal.

Histological examination of the biopsy specimen taken 


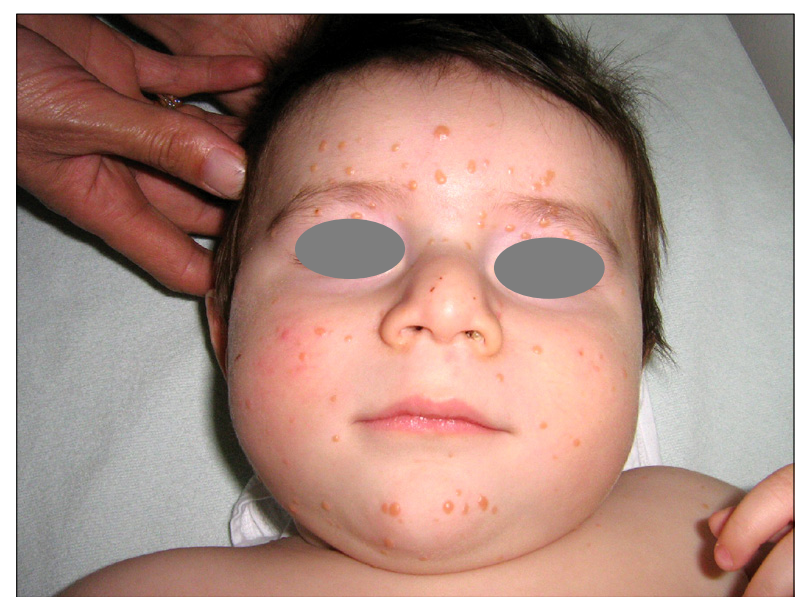

Fig. 1. Small yellow-red papules scattered on the face, forehead and chin.

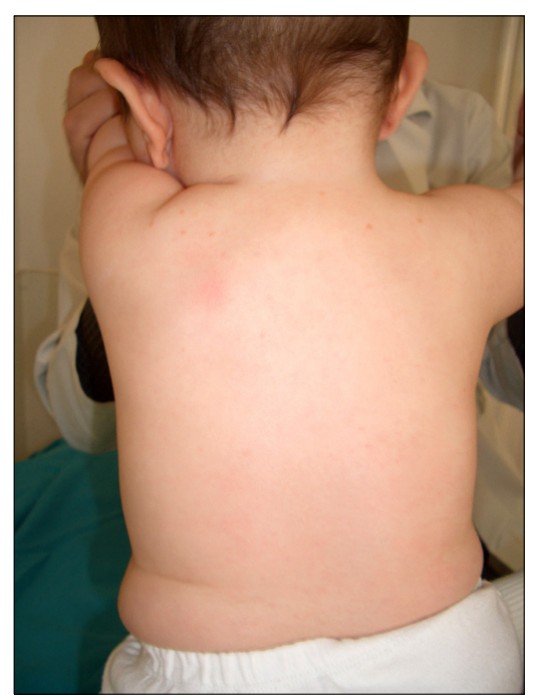

Fig. 2. Discrete small yellow-red papules seen on the upper back.

from a lesion on the left shoulder showed a normal epidermis and sufficient proliferation of large, pleomorphic epitheliod histiocytic cells with large cytoplasm within the upper- and mid-dermis without epidermotropism. Mitotic figures, multinucleated giant cells and cytoplasmic lipids were absent. There was an interstitial infiltration of moderate numbers of lymphocytes and scattered eosinophils (Fig. 3). In the immunohistochemistry analysis, the cells were stained positive for CD68, but negative for the S100 protein and CD1a (Fig. 4). According to the clinicopathologic findings, the disease was diagnosed as benign cephalic histiocytosis, a type of non-Langerhans cell histiocytic disorder.

Three months after his initial visit, none of the skin lesions had regressed and new lesions developed on the upper

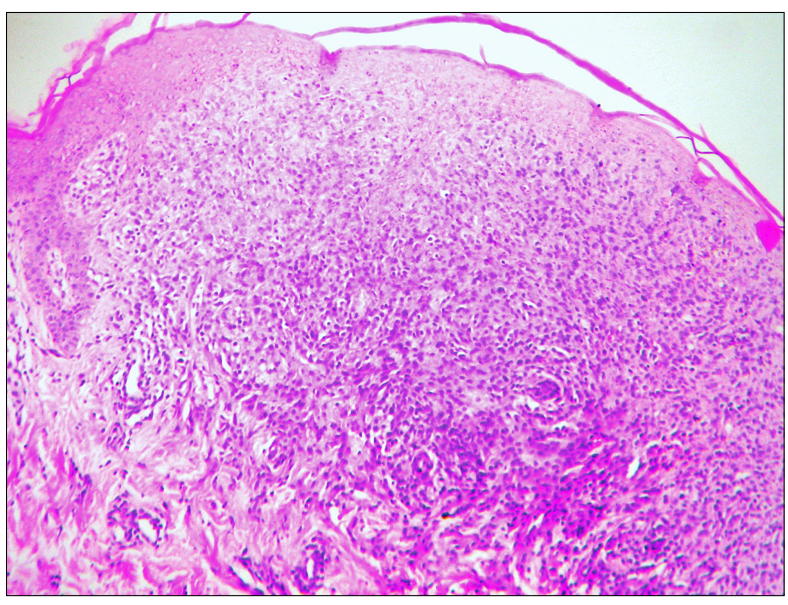

Fig. 3. Proliferations of pleomorphic epitheliod histiocytic cells within the upper- and mid-dermis ( $\mathrm{H} \& \mathrm{E}$, original magnification $\times 100$ ).

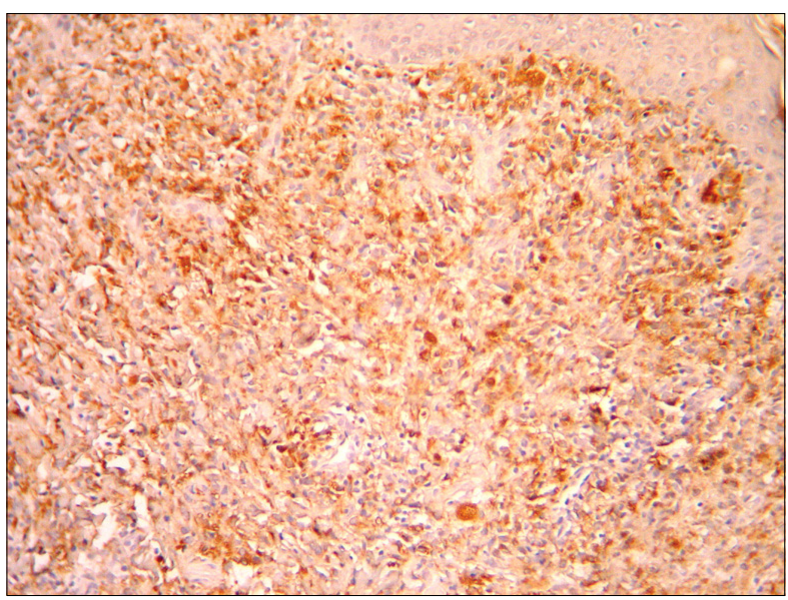

Fig. 4. Immunohistochemistry was positive stained for CD68 (biotin-streptavidin peroxidase system, DAB, original magnification $\times 200)$.

trunk and upper limbs.

\section{DISCUSSION}

$\mathrm{BCH}$ is a rare non-Langerhans cell histiocytosis of unknown etiology that is presented as a self-healing eruption in the head and neck ${ }^{2}$. Since the initial description of this disorder by Gianotti et al. there have been 42 reported cases in various races in the English language literature ${ }^{2,4,5}$. The clinical findings are asymptomatic, macules and papules that are $1 \sim 8 \mathrm{~mm}$ in diameter with colors ranging from yellow to red brown, which first appear on the upper half of the body, mainly on the face and neck. Lesions may subsequently extent to the upper and lower extremity, and buttocks. Consistent with other reported cases, 
our patient had multiple, 2 to $5 \mathrm{~mm}$ yellow-red monomorphic papules that first appeared on the face and later spread onto the upper part of the body and upper extremities. Mucous membranes, palms, soles, and visceral organs have not been reported to be involved in this disease ${ }^{6-9}$. The lesions appear at ages ranging from 2 to 66 months (average 15 months). In approximately 50\% of cases, the patients are younger than 6 months. Males and females are affected equally. Spontaneous regression of lesions begins on an average between 8 to 48 months and complete regression occurs on an average at 50 months, leaving hyperpigmented macules, but not scars ${ }^{2}$. Unfortunately, in our case, we only did a follow-up after 3 months; therefore, it was impossible to see regression of the lesions. Although systemic disease has not been associated with $\mathrm{BCH}$, two articles have reported that $\mathrm{BCH}$ was associated with diabetes insipidus or insulin-dependent diabetes mellitus ${ }^{10,11}$. We did not find any association with other diseases in our case.

The histopathological features show well-circumscribed histiocytic infiltrates in the superficial to mid-reticular dermis. Cells were characterized by the presence of polymorphic nuclei, pale chromatin and abundant cytoplasm without cytoplasmic lipids. There are also inflammatory infiltrates composed of lymphocytes and rarely eosinophils. Although older lesions may contain giant cells, Touton giant cells or foam cells are not present ${ }^{3}$. Electron microscopy showed worm-shaped or comma-shaped bodies in the cytoplasm of $5 \sim 30 \%$ of the histiocytes. In contrast with Langerhans' cell histiocytosis $(\mathrm{LCH})$, Birbeck granules are absent ${ }^{6}$. Immunohistochemical staining of lesional cells demonstrates positive staining for macrophage/ histiocytic markers, including factor XIIla and CD68, whereas they remain negative for Langerhans markers, including S100 protein and CD1 $\mathrm{a}^{12}$.

$\mathrm{BCH}$ must primarily be differentiated from micronodular form of JXG and $\mathrm{GEH}^{6,8}$. Furthermore, $\mathrm{LCH}$, plane warts, urticaria pigmentosa, lichenoid sarcoidosis and multiple Spitz nevi can be confused with $\mathrm{BCH}$. Plane wart, Spitz nevi, urticaria pigmentosa can be distinguished by histologic examination. Lesions of JXG are not usually limited to the head and neck, but rather are more widely distributed over the entire body. In addition, extracutaneous involvement occurs most significantly in the eyes. Histologic examination shows foamy cells and Touton giant cells ${ }^{8,9}$. GEH is more common in adults, with a more extensive distribution of lesions and occasional mucosal involvement. The histologic appearance may be similar to $\mathrm{BCH}^{13,14}$. $\mathrm{LCH}$ has more widespread skin and visceral organ involvement and are positive for S100 and CD1a. Ultrastructural studies also showed the presence of
Birbeck granules in $\mathrm{LCH}^{9}$.

Recent studies and case reports have indicated that $\mathrm{BCH}$ may have overlapping clinical and histologic features with JXG and GEH. Lesions of $\mathrm{BCH}$ was shown to transform into JXG in 2 cases $^{15,16}$. Sidwell et al. reported an infant with a congenital form of non- $\mathrm{LCH}$ with clinical and histologic features of both disseminated JXG and $\mathrm{BCH}^{8}$. A case of $\mathrm{GEH}$ was also reported many years after complete regression of $\mathrm{BCH}^{17}$. In addition, in a blinded histological study by Gianotti et al, $50 \%$ of $\mathrm{BCH}$ cases could not be definitely distinguished form $\mathrm{GEH}$ and early nonxanthomatous $\mathrm{JXG}^{12}$. It has been suggested that $\mathrm{BCH}$ represents an abortive form of JXG rather than a separate entity $^{16,18}$. The occurrence of $\mathrm{BCH}$ as a localized form of $\mathrm{GEH}$ in children was rarely reported ${ }^{13,19}$. The relationship of $\mathrm{BCH}$ with JXG and $\mathrm{GEH}$ is still not clear. Therefore, some authors have claimed that $\mathrm{BCH}$, JXG and $\mathrm{GEH}$ belong to the same clinical entity. As a result, further research and data accumulation of cases are required to explain the relationship and pathogenesis between all of the non-Langerhans histiocytosis.

\section{REFERENCES}

1. Gianotti F, Caputo R, Ermacora E. Singular "infantile histiocytosis with cells with intracytoplasmic vermiform particles". Bull Soc Fr Dermatol Syphiligr 1971;78:232-233.

2. Jih DM, Salcedo SL, Jaworsky C. Benign cephalic histiocytosis: a case report and review. J Am Acad Dermatol 2002; 47:908-913.

3. Zelger BW, Sidoroff A, Orchard G, Cerio R. Non-Langerhans cell histiocytoses. A new unifying concept. Am J Dermatopathol 1996; 18:490-504.

4. Dadzie O, Hopster D, Cerio R, Wakeel R. Benign cephalic histiocytosis in a British-African child. Pediatr Dermatol 2005;22:444-446.

5. Hasegawa S, Deguchi M, Chiba-Okada S, Aiba S. Japanese case of benign cephalic histiocytosis. J Dermatol 2009;36: 69-71.

6. Baler JS, DiGregorio FM, Hashimoto K. Facial papules in a child. Benign cephalic histiocytosis. Arch Dermatol 1995; 131:610-1, 613-4.

7. Gianotti F, Caputo R, Ermacora E, Gianni E. Benign cephalic histiocytosis. Arch Dermatol 1986;122:1038-1043.

8. Sidwell RU, Francis N, Slater DN, Mayou SC. Is disseminated juvenile xanthogranulomatosis benign cephalic histiocytosis? Pediatr Dermatol 2005;22:40-43.

9. Watabe H, Soma $\mathrm{Y}$, Matsutani $\mathrm{Y}$, Baba T, Mizoguchi $M$. Case 2: benign cephalic histiocytosis. Clin Exp Dermatol 2002;27:341-342.

10. Saez-De-Ocariz M, Lopez-Corella E, Duran-McKinster C, Orozco-Covarrubias L, Ruiz-Maldonado R. Benign cephalic histiocytosis preceding the development of insulindependent diabetes mellitus. Pediatr Dermatol 2006;23: 
101-102.

11. Weston WL, Travers SH, Mierau GW, Heasley D, Fitzpatrick J. Benign cephalic histiocytosis with diabetes insipidus. Pediatr Dermatol 2000;17:296-298.

12. Gianotti R, Alessi E, Caputo R. Benign cephalic histiocytosis: a distinct entity or a part of a wide spectrum of histiocytic proliferative disorders of children? A histopathological study. Am J Dermatopathol 1993;15:315-319.

13. Caputo R, Ermacora E, Gelmetti C, Berti E, Gianni E, Nigro A. Generalized eruptive histiocytoma in children. J Am Acad Dermatol 1987; 17:449-454.

14. Winkelmann RK, Kossard S, Fraga S. Eruptive histiocytoma of childhood. Arch Dermatol 1980;116:565-570.

15. Rodriguez-Jurado R, Duran-McKinster C, Ruiz-Maldonado R. Benign cephalic histiocytosis progressing into juvenile xanthogranuloma: a non-Langerhans cell histiocytosis transforming under the influence of a virus? Am J Dermatopathol 2000;22:70-74.

16. Zelger BG, Zelger B, Steiner H, Mikuz G. Solitary giant xanthogranuloma and benign cephalic histiocytosis--variants of juvenile xanthogranuloma. $\mathrm{Br}$ J Dermatol 1995;133: 598-604.

17. Aliaga $A$, Alegre VA, Hernández $M$, Febrer MI, Martinez $A$, Portea JM. Benign cephalic histiocytosis vs generalized eruptive histiocytoma. J Cutan Pathol 1989;16:293-296.

18. Goday JJ, Raton JA, Landa N, Eizaguirre X, Diaz-Pérez JL. Benign cephalic histiocytosis-study of a case. Clin Exp Dermatol 1993;18:280-282.

19. Umbert IJ, Winkelmann RK. Eruptive histiocytoma. J Am Acad Dermatol 1989;20:958-964. 